\title{
Path analysis of flipped English classroom in Higher Vocational Colleges Based on Internet online platform
}

\author{
Xiaoli Zhang ${ }^{1}$ \\ ${ }^{1}$ Fujian Preschool Education College, Fujian, 350007
}

\begin{abstract}
English education and teaching under the background of "curriculum ideological and political", and expounds the relevant application strategies of "curriculum ideological and political" in English teaching, so as to improve the teaching efficiency. With the continuous improvement of quality education, in English teaching, mainly from the "moral education" as the teaching goal, teachers should not only explain the relevant theoretical knowledge for students, but also make students' Ideological and moral quality, so as to make the students' overall quality develop.
\end{abstract}

\section{Introduction}

With the continuous development of quality education, the curriculum education system should also be constantly improved, so that all disciplines and ideological and political courses can be closely linked. With the continuous improvement of the teaching system and the reform, the teaching of moral education has been attached great importance by most educators. Under the reform of the new era, the traditional English teaching mode and teaching ideas are no longer satisfied with the modern teaching mode. English teaching should keep up with the development of the times, so as to effectively integrate "Curriculum Ideology" into various teaching, from different aspects Starting from the level, further improve the core quality and comprehensive quality of students.

\section{Related concepts of curriculum ideological and Political Education}

The course of Ideological and political education is to "integrate the ideological and political into various disciplines, and cultivate students' core literacy ability from different levels", so as to find the relevance between various disciplines and ideological and political, and effectively integrate ideological and political into the learning of disciplines when teachers are teaching, so as to achieve the purpose of Ideological and political teaching through the continuous infiltration of teaching 。The manifestation of curriculum ideological and political education is mainly embodied in the continuous and systematic curriculum view. Its teaching mode is not only limited to teaching professional knowledge, but also allows the ideological and political education to be combined with various disciplines, so as to teach students to educate people through the study of subject knowledge, and form a complete teaching system.

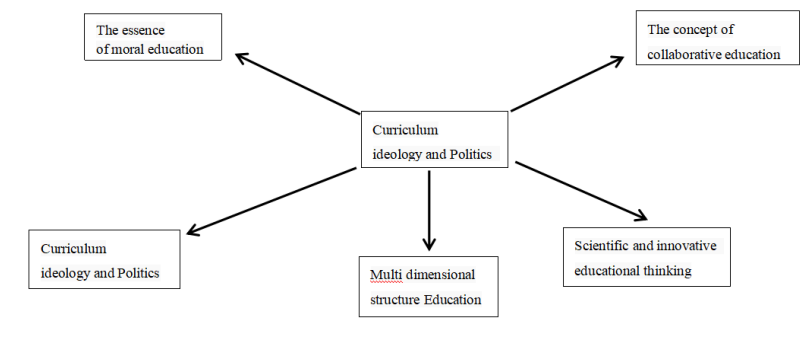

\section{Current situation of English Teaching}

English learning is necessary and practical, but at present, there are still many problems in English teaching, not only students' learning, but also teachers' teaching ability.

\subsection{Students are utilitarian in learning English}

Language is the most basic language of communication between people. English learning is to communicate effectively with others. But from the students' learning state, students' learning motivation has a strong utilitarian. At the same time, some students will learn because they want their English Certificate "gilded". Such a learning attitude not only can not bring positive influence to students, but also has no specific significance to improve their own value. It can be seen that students learn English in order to get a certificate, not because English itself wants to learn, this phenomenon is still common. This reflects a drawback, let students learn English well is not to cultivate students' interest in English, but to learn English as a process, thus producing unnecessary influence.

\subsection{There are some deviations in Teachers' teaching concerns}

Most enterprises will consider the students' English level 
when employing, but what they don't consider is the students' actual English level, which leads to the deviation of teachers' teaching focus. Most of them are to cater to the characteristics of enterprises. "Exam oriented education" is the main feature of English teaching. The purpose of teachers' teaching is not to cultivate students' enthusiasm for English learning, but mainly to improve students' English scores and teach students the skills of English examination, such as "three short and one long, choose the longest" and "if you can't choose D", although such a way can help students, if it goes on for a long time, learn Students will have a fluke mind, relax on English learning, which will bring negative impact. But in the ideological and political teaching system, such a way can be completely abandoned, mainly according to students' interest in learning to arrange reasonable teaching content, so that students have a high interest in English, which is conducive to English learning, so as to find English learning skills and improve English learning level.

\section{New ideas of English Teaching under the ideological and political system of curriculum}

English is an indispensable course in the process of students' learning, and it is also the main learning subject. In order to better realize the ideological and political teaching, we need to develop all kinds of courses and ideological and political together. It can be seen that some schools have regarded English as the main teaching position of Ideological and political education. Meanwhile, in the process of teaching, more ideological and political teaching contents of socialist core values are integrated into the teaching process, which can make English classroom get a higher breakthrough in teaching. Traditional English teaching has some limitations in the teaching mode. The purpose of teaching is to improve students' English level, but it does not pay attention to students' quality education. This kind of teaching idea is contrary to the requirements of quality education, which is not conducive to the overall development of students.

Under the ideological and political teaching system, English teaching should change the previous teaching ideas, not only to arrange reasonable course teaching, but also to pay attention to the selection of curriculum knowledge, and to formulate reasonable teaching plan according to the teaching system of Ideological and political course. Ideological and political education has always been the focus of teaching philosophy, but for some reasons, the ideological and political education has not been effectively implemented. With the continuous development of society, more and more English talents are available. Therefore, teachers should not only teach students theoretical knowledge, but also pay attention to students' Ideological and political education. Some enterprises will provide some special "test papers" when employing people, and there are many similarities with the civil service examination papers. At the same time, enterprises also require students to have a correct outlook on life, world outlook and values. Therefore, it is necessary for each school to strengthen the ideological and political education of students, so as to improve the comprehensive ability and quality of students. Under the teaching mode of Ideological and political courses, schools should have certain teaching ideas and means, and integrate certain ideological and political knowledge into the process of teaching students' theoretical knowledge, so as to promote the continuous improvement of quality education and form correct moral concepts.

\section{College English teaching strategies under the ideological and political system of curriculum}

Under the teaching mode of Ideological and political education, teachers should integrate more teaching contents of ideological renovation course while teaching students English. So that students can have a certain critical thinking ability, a correct view of the relationship between teachers and students, and further play the role of students in learning. Under the ideological and political teaching system, teachers should also play the essence of English learning, and further realize the educational function in English teaching, so as to achieve the purpose of English Teaching under the ideological and political course.

\subsection{Optimizing English curriculum knowledge}

While teaching students English knowledge, teachers should have enough ideological and political theory knowledge, at the same time, they can effectively integrate ideological knowledge into English teaching, so as to avoid unnecessary conflicts. In the process of teaching, teachers should not only become the guide of classroom teaching, but also become the partner of students in the learning process, actively interact with students, and then make the distance between students and teachers closer, so that students' learning content is closer to life. In the process of teaching students, teachers can also show students excellent learning platform through Internet technology, such as micro class, MOOC, etc., so that students can go out of the classroom and carry out autonomous learning after class. If you want to improve your English learning ability, you should take learning English as a habit. English learning is a long process, which needs the students to accumulate constantly. We should not only rely on the enthusiasm of one brain, but also find a suitable way to learn English, so as to improve English learning.

\subsection{Guide students to form a correct attitude towards English learning}

For utilitarian learning, it may have a greater impact on short-term English learning, and it will improve students' English learning performance, but for the future development, there is no more help, so English teachers should guide students to form a correct attitude towards English learning while teaching English. The development of Ideological and political teaching is conducive to the 
development of students' behavior habits and learning attitude, especially in the ideological and political system of curriculum, the utilitarian learning mode of students should be abandoned. At the same time, teachers should also make changes in the teaching mode and educate students from the perspective of Ideological and political education, so that students can understand the truth that "there is no shortcut to success", and further enable students to learn English on a down-to-earth basis, so as to realize the development of outlook on life, values and world outlook.

\subsection{Reform English teaching system}

In the past, the traditional English teaching mode is not in line with the modern pre class ideological and political English teaching mode, so the English teaching mode should be constantly innovated. Therefore, teachers should form the main teaching concept in the teaching mode. Although the teaching content has been reformed, the teaching method should also have the characteristics of selectivity. At the same time, the reform of English teaching system also needs the joint efforts of students' teachers. Students should provide relevant opinions for the reform of teaching system, and ask for additional responses. Teaching should be carried out according to the actual situation of students' learning. No matter what kind of English teaching system is presented, the main features of Ideological and political education should be retained. Such a requirement not only meets the teaching mode of Ideological and political courses, but also lays a solid foundation for the development of Ideological and political education in English class; besides the first time, it also meets the needs of quality education, so that the moderator students can form a correct attitude towards English learning.

\section{Strengthening teachers' Ideological and political consciousness}

Teachers are not only the guide of students, but also the participants in the learning process. The professional quality of teachers can directly affect the learning results of students. Therefore, the teaching mode of "curriculum ideological and political" first enables teachers to enhance their own ideological and political awareness, so as to realize the importance of ideological and political education, and further carry out teaching according to the actual situation of students' learning. The school can also regularly carry out relevant symposiums on "curriculum ideological and political", so that teachers can get a comprehensive understanding of it. At the same time, teachers can also guide students to actively participate in the teaching of English ideological and political education. In addition, teachers should also set up their own learning objectives, so as to correctly pass on the values of imperial township to students. In the process of teaching, English teachers should set up a positive example for students and influence students from their own behavior, so as to realize the ideological and moral quality, and influence the students, and realize the effective teaching of "curriculum ideological and political".

\section{Enrich the content of English textbooks}

English teaching materials are necessary and effective ways for students to learn. However, from the current situation, most of the English teaching materials do not accurately penetrate the ideological and political concepts, and lack some ideological and political elements. Therefore, schools need to select rich teaching materials for students while selecting textbooks, so as to make English classroom teaching have certain ideological and political ideas Highlights the main culture of our country, mainly including: socialist core values, excellent traditional virtues and culture. For example, in the process of learning textbooks, we can add articles related to Chinese economy or culture; we can also set debate questions or discussion questions between Chinese and Western cultures in the practice after class. In addition, we can also guide students to use English to introduce our culture, so as to get better exercise, and let students gain self-confidence in English learning.

\section{Conclusion}

To sum up, in the context of "curriculum ideological and political", with the continuous reform of education, English teaching has a higher requirement of teaching objectives. If the traditional teaching mode is still applied in the process of English teaching, it is no longer in line with the rapid development of society. Therefore, teachers' teaching process should be based on the traditional teaching mode The continuous reform of "curriculum ideological and political" teaching mode into English teaching effectively, so as to get further implementation, and enable students to establish a high degree of Ideological and cognitive, so as to develop good behavior habits, effective English learning, from the English form and history and other different levels to re understand English; not only that, teachers should also let their own The consciousness of ideological renovation has been strengthened constantly, so as to set an example for students to learn from. In addition, the teaching content of English teaching materials should also be constantly improved, integrating into a certain amount of Chinese ideological and political education, through diversified teaching methods, English teaching mode can be improved, and then the comprehensive quality of students can be cultivated.

\section{Reference}

1. Chen Yi. Communication of Chinese culture and College English Teaching Reform [J]. Journal of Hubei second normal university, 2020,37 (03): 99104

2. He Fang. College English Teaching under the ideological and political system of curriculum [J]. Education and teaching forum, 2019 (28): 32-33 
3. Niu Shenming. On the application of Chinese excellent traditional culture in English Teaching [J]. Journal of Shanxi Radio and TV University, 2019, 24 (02): 20-24 